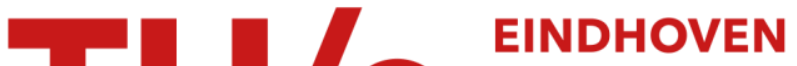 UNIVERSITY OF TECHNOLOGY
}

\section{Structure-based design of non-natural macrocyclic peptides that inhibit protein-protein interactions}

Citation for published version (APA):

Krüger, D. M., Glas, A., Bier, D., Pospiech, N., Wallraven, K., Dietrich, L., Ottmann, C., Koch, O., Hennig, S., \& Grossmann, T. N. (2017). Structure-based design of non-natural macrocyclic peptides that inhibit protein-protein interactions. Journal of Medicinal Chemistry, 60(21), 8982-8988. https://doi.org/10.1021/acs.jmedchem.7b01221

DOI:

10.1021/acs.jmedchem.7b01221

Document status and date:

Published: 09/11/2017

\section{Document Version:}

Publisher's PDF, also known as Version of Record (includes final page, issue and volume numbers)

\section{Please check the document version of this publication:}

- A submitted manuscript is the version of the article upon submission and before peer-review. There can be important differences between the submitted version and the official published version of record. People interested in the research are advised to contact the author for the final version of the publication, or visit the $\mathrm{DOI}$ to the publisher's website.

- The final author version and the galley proof are versions of the publication after peer review.

- The final published version features the final layout of the paper including the volume, issue and page numbers.

Link to publication

\section{General rights}

Copyright and moral rights for the publications made accessible in the public portal are retained by the authors and/or other copyright owners and it is a condition of accessing publications that users recognise and abide by the legal requirements associated with these rights.

- Users may download and print one copy of any publication from the public portal for the purpose of private study or research.

- You may not further distribute the material or use it for any profit-making activity or commercial gain

- You may freely distribute the URL identifying the publication in the public portal.

If the publication is distributed under the terms of Article 25fa of the Dutch Copyright Act, indicated by the "Taverne" license above, please follow below link for the End User Agreement:

www.tue.nl/taverne

Take down policy

If you believe that this document breaches copyright please contact us at:

openaccess@tue.nl

providing details and we will investigate your claim. 


\title{
Structure-Based Design of Non-natural Macrocyclic Peptides That Inhibit Protein-Protein Interactions
}

\author{
Dennis M. Krüger, ${ }^{\dagger,, \S, \#}$ Adrian Glas, ${ }^{\dagger, \ddagger, \#}$ David Bier, ${ }^{\dagger, \perp}$ Nicole Pospiech, ${ }^{\dagger}$ Kerstin Wallraven, ${ }^{\dagger}$

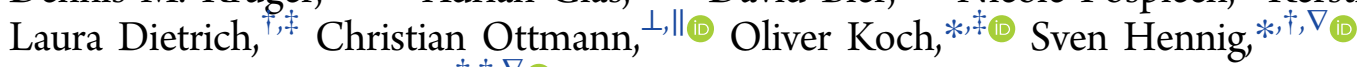 \\ and Tom N. Grossmann $*,+,+, \nabla_{\odot}$ \\ ${ }^{\dagger}$ Chemical Genomics Centre of the Max Planck Society, Otto-Hahn-Str. 15, 44227 Dortmund, Germany \\ ${ }^{\ddagger}$ Faculty of Chemistry and Chemical Biology, TU Dortmund University, Otto-Hahn-Str. 6, 44227 Dortmund, Germany \\ ${ }^{\perp}$ Department of Chemistry, University of Duisburg-Essen, Universitätstr. 7, 45141 Essen, Germany \\ "Department of Biomedical Engineering, Institute of Complex Molecular Systems, Eindhoven University of Technology, Den Dolech \\ 2, 5612 AZ Eindhoven, The Netherlands \\ ${ }^{\nabla}$ Department of Chemistry \& Pharmaceutical Sciences, VU University Amsterdam, De Boelelaan 1083, 1081 HV Amsterdam, The \\ Netherlands
}

\section{Supporting Information}

ABSTRACT: Macrocyclic peptides can interfere with challenging biomolecular targets including protein-protein interactions. Whereas there are various approaches that facilitate the identification of peptide-derived ligands, their evolution into higher affinity binders remains a major hurdle. We report a virtual screen based on molecular docking that allows the affinity maturation of macrocyclic peptides taking non-natural amino acids into consideration. These macrocycles bear large and flexible substituents that usually complicate the use of docking approaches. A virtual library containing more than 1400 structures was screened against the target focusing on docking poses with the core structure resembling a known bioactive conformation. Based on this screen, a macrocyclic peptide $\mathbf{2 2}$ involving two non-natural amino acids was evolved showing increased target affinity and biological activity. Predicted binding modes were verified by X-ray crystallography. The presented workflow allows the screening of large macrocyclic peptides with diverse modifications thereby expanding the accessible chemical space and reducing synthetic efforts.

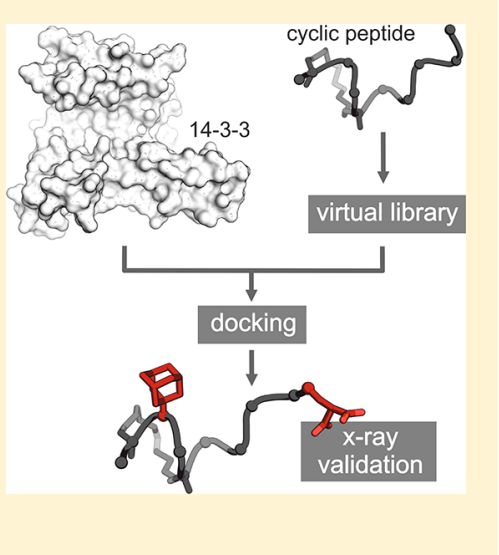

\section{INTRODUCTION}

Macrocyclic scaffolds are a common structural element among natural products, and they are considered promising candidates for the development of chemical probes and novel therapeutics. ${ }^{1,2}$ This is mainly due to their ability to bind protein surfaces even if those lack distinct binding pockets. The presence of such pockets is often required for high affinity binding of classic small molecules. ${ }^{3-5}$ Protein-protein interactions (PPIs) tend to involve flat surfaces rendering their inhibition extremely challenging. Among macrocycles, peptide-derived structures proved to be particularly valuable starting points for the generation of PPI inhibitors. ${ }^{2}$ Often, the design process starts by macrocyclization of known peptide binding epitopes, ${ }^{2}$ or by the screening of macrocyclic peptide libraries (e.g., via phage or mRNA display) ${ }^{6,7}$ resulting in structures that often exhibit good affinity for their target. However, in most cases an evolution toward higher affinity ligands is required to efficiently block PPIs and/or to compensate for affinity losses during the optimization process toward increased bioavailability. ${ }^{2}$ For that reason, affinity maturation constitutes a bottleneck preventing straightforward use of bioactive macrocyclic peptides. Ideally, the consideration of numerous modifications including natural and non-natural amino acids at all positions of the peptide sequence would be desired.

Given the efforts associated with the chemical synthesis and evaluation of large peptide libraries ${ }^{8}$ and the complexity of biological screening platforms as well as their restriction to a limited number and type of non-natural building blocks, ${ }^{6,7}$ computational screening approaches provide an appealing alternative. In the case of small molecules and short peptide ligands, virtual screening based on molecular docking has proven particularly useful. ${ }^{9-13}$ For macrocyclic scaffolds with relatively small substituents, benchmark studies were able to reproduce known binding modes indicating that docking could also be applied. ${ }^{14-16}$ However, it is not clear if these approaches allow exhaustive virtual screening and the prediction of novel interactions as molecular docking encounters severe difficulties in scoring new binding modes for extended scaffolds. ${ }^{12,13}$ In particular, the consideration of macrocycles with large and flexible substituents, as they are often found in peptide-derived

Received: August 18, 2017

Published: October 13, 2017 
PPI inhibitors, ${ }^{2}$ can be expected to be extremely challenging. For this reason, computationally more demanding methods such as molecular dynamics simulations have been used for protein-peptide docking, ${ }^{17-19}$ however, at the cost of a dramatically reduced throughput. ${ }^{20-23}$ An additional challenge in the affinity maturation of macrocyclic ligands occurs when the starting point already shows good target affinity. ${ }^{10}$ In this case, a precise prediction and scoring of the binding mode is of utmost importance to allow the identification of improved ligands. ${ }^{10}$ The availability of fast and reliable docking approaches for modified peptide ligands would accelerate the time-consuming optimization process and is highly desired.

Herein, we describe a computational approach based on molecular docking that allows the affinity maturation of macrocyclic peptide ligands. Originally derived from linear bacterial peptide sequence $\mathbf{1}$ (ESp), ${ }^{24}$ macrocyclic peptide 2 $\left(\beta_{\text {ss }} 12\right)^{24}$ served as a starting point. Based on the crystal structure of 2 in complex with its target protein 14-3-3, a virtual library of macrocycles was generated, which was screened against the target. Subsequently, binding poses that resemble the backbone conformation of the starting peptide in its bound state were scored. This selection process allowed the identification of a macrocyclic peptide with two non-natural amino acids, which exhibits increased target affinity as well as increased potency in cell-based assays. Most importantly, predicted side chain binding modes were verified by X-ray crystallography.

\section{RESULTS}

Virtual Peptide Library. Aiming for a computational approach that allows the handling of large and flexible structures, we choose macrocyclic peptide $\mathbf{2}$ as model system. $^{24,25}$ This peptide binds 14-3-3 proteins which form a family of closely related adaptor proteins that regulates a wide range of cellular processes via numerous PPIs. Peptide 2 involves an 11-mer irregularly structured peptide sequence (dark gray, Figure 1), which is constrained by a hydrophobic

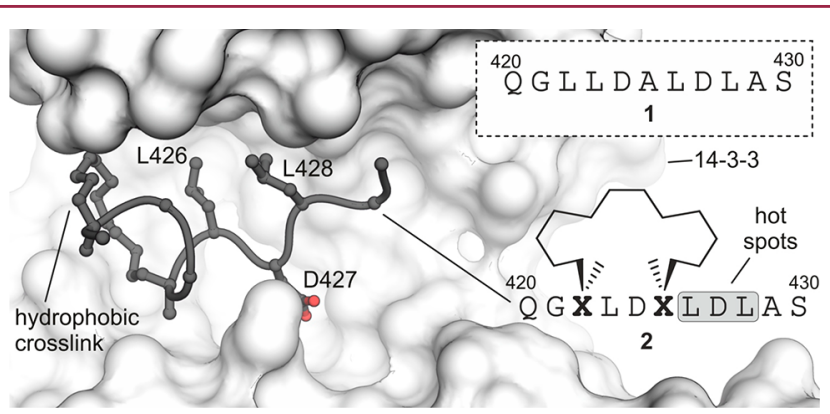

Figure 1. Sequence of linear peptide 1 and crystal structure of cyclic peptide 2 (dark gray) bound to $14-3-3 \zeta$ (light gray, PDB ID 4 n84). Cross-link and hotspot residues (L426, D427, and L428) are shown explicitly. Peptide sequence of 2 and chemical structure of cross-link are shown (Residues are numbered in accordance to PDB ID 4n84).

side chain-to-side chain cross-link in analogy to so-called hydrocarbon-stapled peptides. ${ }^{26,27}$ It was originally derived from the natural peptide epitope $1 .{ }^{24}$ Macrocycle 2 binds to the amphipathic groove of 14-3-3, which recognizes certain phosphorylated proteins and some nonphosphorylated peptide epitopes. Among the synthetic 14-3-3 binders, macrocyclic peptide 2 is the highest affinity ligand $\left(K_{\mathrm{d}} \approx 0.1 \mu \mathrm{M}\right){ }^{24,28-34}$ Its relatively high affinity, molecular weight $(M=1280 \mathrm{~g}$ $\mathrm{mol}^{-1}$ ) and flexibility render peptide 2 a challenging starting point for any in silico affinity optimization. The crystal structure of 2 (PDB ID $4 n 84)^{24}$ in complex with isoform zeta of 14-3-3 $(14-3-3 \zeta)$ served as starting point for our work. All following calculations and biophysical as well as biological experiments were performed with $14-3-3 \zeta$.

Initially, the contribution of all side chains of peptide 2 to 14-3-3 $\zeta$ binding was assessed employing an alanine scan (Figure S1). This revealed three hotspot residues (L426, D427, and L428, Figure 1) at which alanine substitution results in dramatically reduced affinity ( $>10$-fold, Figure S1). Preceding tests reveal that even minor changes at a hotspot position result in severe affinity reduction (Figure S2). We concluded that variation of these residues is unlikely to result in derivatives with increased binding affinity and focused on the remaining six amino acids (Figure 1). A virtual amino acid library was assembled (Table S2) containing all proteinogenic amino acids (except for glycine and proline) and 223 nonproteinogenic ones. These amino acids were selected based on two criteria: (i) commercial availability of suitably protected analogs allowing a direct use in solid-phase peptide synthesis (SPPS) and (ii) coverage of a diverse chemical space preventing the accumulation of closely related derivatives (Figure S3). Incorporation of all amino acids into the six positions of interest results in a virtual library of 1446 peptides.

Molecular Docking of Virtual Library. Given the successful utilization of molecular docking and scoring approaches for the virtual screening of small molecules and the achievements with respect to small peptide ligands, $9,12,35,36$ we decided to peruse this strategy. Macrocycle $\mathbf{2}$ bears large and flexible substituents, features that affect the validity of docking poses and scoring. To reduce the number of invalid docking poses, we considered the implementation of a checkpoint after library docking that would allow focusing on the most relevant docking poses for subsequent scoring. Knowing the importance of the three hotspot residues for binding, we reasoned that high affinity binders will most likely adopt a conformation that positions those residues in analogy to 14-3-3-bound 2. For that reason, pose filtering was applied, ensuring that only docking poses were considered for which the central hotspot amino acids (426-428) resemble the conformation of peptide 2 in its bound state (allowed RMSD $\leq 2.0 \AA$ ). These considerations resulted in the following workflow in which the

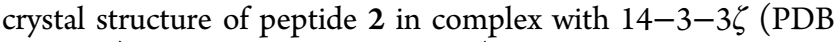
ID $4 n 84$ ) served as starting point (for details see Supporting Information). First, the coordinates of $\mathbf{2}$ were extracted, and each of the six selected residues was iteratively substituted by each member of the virtual amino acid library (241 building blocks). This resulted in a database of 1446 macrocyclic peptides each of them bearing a single residue variation compared to 2 . Second, docking parameters were adjusted to ensure that the conformation of 2 bound to $14-3-3$ is reproduced upon docking. These parameters were then used to dock each peptide into the amphipathic groove of $14-3-3 \zeta$ using AutoDock Vina ${ }^{35}$ to sample the conformational space. Thereafter, above-mentioned pose filtering was applied followed by a final rescoring step. For rescoring of docking poses of small peptides, it was shown to be beneficial to consider a combination of knowledge-based and empirical scoring functions since they provide complementary hit lists. ${ }^{12,37}$ In this respect, Astex Statistical Potential ${ }^{38}$ (ASP, knowledge-based) and ChemScore ${ }^{39}$ (empirical) have been described to be suitable for the scoring of peptide 
conformations $^{12}$ and were thus selected for rescoring. ${ }^{40}$ For each peptide, the remaining poses (after pose filtering) were rescored, and only the highest scoring one was considered for the final ranking. For each of the six amino acid positions, the top five ranking peptides per scoring function were visually inspected (in total 60 complexes) to select one peptide per scoring function ( ${ }^{\#}$ ChemScore, ${ }$ ASP) and position for experimental validation (in total 12 peptides 10-21, Figure 2 and Figure S4).

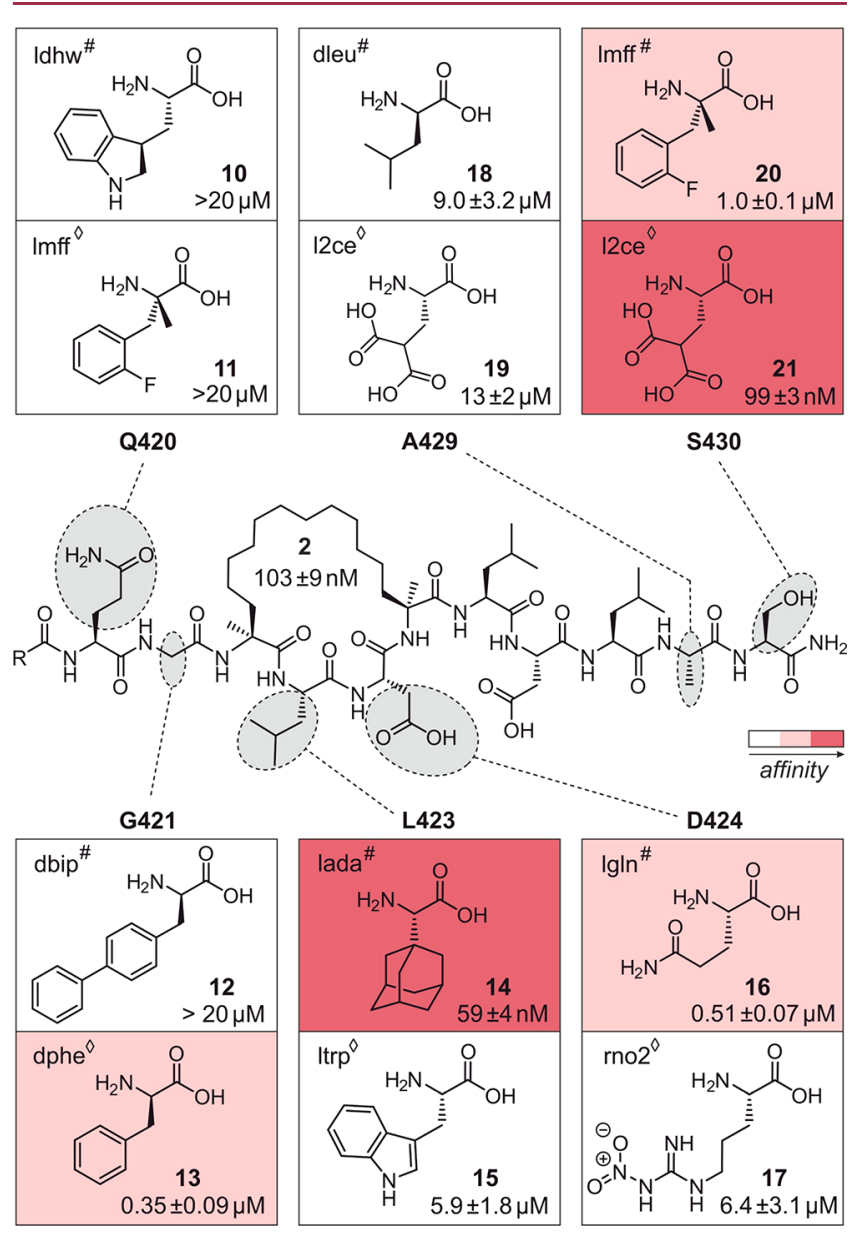

Figure 2. Chemical structure of $\mathbf{2}$ with varied residues highlighted in gray. Selected 12 variations are shown (two per position: one obtained from ChemScore (\#) and the other one from ASP $(\diamond)$ hit list). Experimentally determined dissociation constants $\left(K_{\mathrm{d}}\right)$ for corresponding peptides 10-21 with $14-3-3 \zeta$ are given (for details see Figure S7). Variations are color coded in accordance to their affinity for $14-3-3 \zeta\left(K_{\mathrm{d}}\right.$ rages: dark red, $<0.1 \mu \mathrm{M}$; light red, $0.1-1 \mu \mathrm{M}$; white, $>1 \mu \mathrm{M})$.

Experimental Affinities and Structural Validation. Fluorescently labeled versions of all 12 peptides were synthesized applying standard protocols for SPPS and macro-

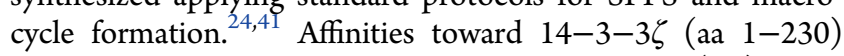
were determined using a fluorescence polarization (FP) assay. As reference, the dissociation constant $\left(K_{\mathrm{d}}\right)$ of 2 was determined $\left(K_{\mathrm{d}}=103 \mathrm{nM}\right)$. Among the 12 peptides (Figure $2)$, seven show relatively low affinities for $14-3-3 \zeta\left(K_{d}>1\right.$ $\mu \mathrm{M}$, white) with four of them still being in the low micromolar range $(6-13 \mu \mathrm{M})$. Five peptides exhibit affinities in the submicromolar range $\left(K_{\mathrm{d}}<1 \mu \mathrm{M}\right.$, light and dark red) rendering them better binders than the wildtype epitope 1. Most strikingly, among those five peptides, there are two that show lower $K_{d}$ values than starting point 2 . In one case, leucine at position 423 (L423) is substituted by $\mathrm{L}$-(1-adamantyl)glycine (lada, peptide 14, $K_{\mathrm{d}}=59 \mathrm{nM}$ ), while in the other one, serine at position $430(\mathrm{~S} 430)$ is substituted by $\mathrm{L}-\gamma$-carboxyglutamic acid (12ce, peptide 21, $\left.K_{\mathrm{d}}=99 \mathrm{nM}\right)$. Whereas the non-natural amino acid $12 \mathrm{ce}$ in $\mathbf{2 1}$ carries a malonic acid side chain predicted to engage a positively charged cavity on $14-3-3 \zeta$ (Figure S5), lada in $\mathbf{1 4}$ bears a bulky and hydrophobic adamantyl moiety presumably interacting with a hydrophobic

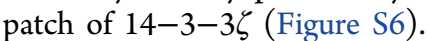

Having identified two variations with increased affinity, we explored the consequences of incorporating both non-natural amino acids simultaneously into the sequence resulting in peptide 22 (AdCe). For a fluorescently labeled version of 22, 14-3-3 affinity was determined using FP. Notably, both variations appear to act additively, resulting in further increased affinity $\left(K_{d}=38 \pm 3 \mathrm{nM}\right.$, Figure 57$)$, which is a 2.7 -fold increase compared to starting peptide $2(103 \pm 9 \mathrm{nM})$. To obtain molecular details of the 22-14-3-3 $\zeta$ interaction and to evaluate the accuracy of our predicted binding modes, we aimed for a crystal structure of the corresponding complex. Cocrystallization of 22 and $14-3-3 \zeta$ (aa 1-230) provided crystals of space group $P 2_{1} 2_{1} 2_{1}$ and allowed the determination of a crystal structure with $2.3 \AA$ resolution (PDB ID 5jm4, Table S3). Each asymmetric unit contains two 14-3-3 proteins, with each harboring one molecule of 22 in its hydrophobic groove (Figure S8). The corresponding $2 \mathrm{~F}_{\mathrm{o}}-\mathrm{F}_{\mathrm{c}}$ density map (Figures S9) allows the identification of the entire peptide except for the side chain of $\mathrm{N}$-terminal amino acid Q420, which is not resolved. Superimposition of 22 (red) and 2 (gray) in complex with $14-3-3 \zeta$ (Figure 3a) reveals good structural overlay (RMSD backbone: $0.67 \AA$ ) verifying analogous binding modes. Most importantly, comparison of the 22 crystal structure with docking predictions for lada at position 423 (Figure 3b) and 12ce at position 430 (Figure 3c) show excellent superimposition. As predicted, the adamantyl moiety of lada engages a hydrophobic patch of the 14-3-3 $\zeta$ groove, and the malonate side chain of $12 \mathrm{ce}$ interacts with two arginines of 14-3-3 $\zeta$ (Figure S10) that are not addressed by 2 . This accuracy of the molecular docking is remarkable, considering that the $\mathrm{C}$-terminal part of the peptide backbone is relatively flexible. Interestingly, lada at position 423 originates from the ChemScore (\#) hit list, while 12ce at position 430 was suggested after ASP $(\diamond)$ rescoring (Figure 2). This underlines the usefulness of considering knowledge-based as well as empirical scoring functions for rescoring.

Inhibition of PPI. Knowing that $\mathbf{2 2}$ exhibits higher affinity for $14-3-3 \zeta$ than 2 (2.7-fold) and wild-type epitope 1 (20fold), we were interested if this results in more efficient competition with PPIs and increased bioactivity. For that purpose, the competition with phosphorylated binding partners of 14-3-3 was considered. Superimposition of 22 (red) and representative phosphorylated peptides (blue) in complex with 14-3-3 shows substantial overlap (Figure 4a), suggesting competitive binding. To test this hypothesis, we performed FP competition experiments employing a Raf-derived phosphorylated peptide ligand (Figure S12) of $14-3-3 \zeta$ as tracer and nonlabeled peptide $\mathbf{1}, \mathbf{2}$, or $\mathbf{2 2}$ as competitor. These measurements (Figure 3b) clearly show efficient competition of 22 (red) with the phosphorylated peptide (half maximal inhibitory concentration: $\mathrm{IC}_{50}=0.8 \mu \mathrm{M}$ ). In line with their 

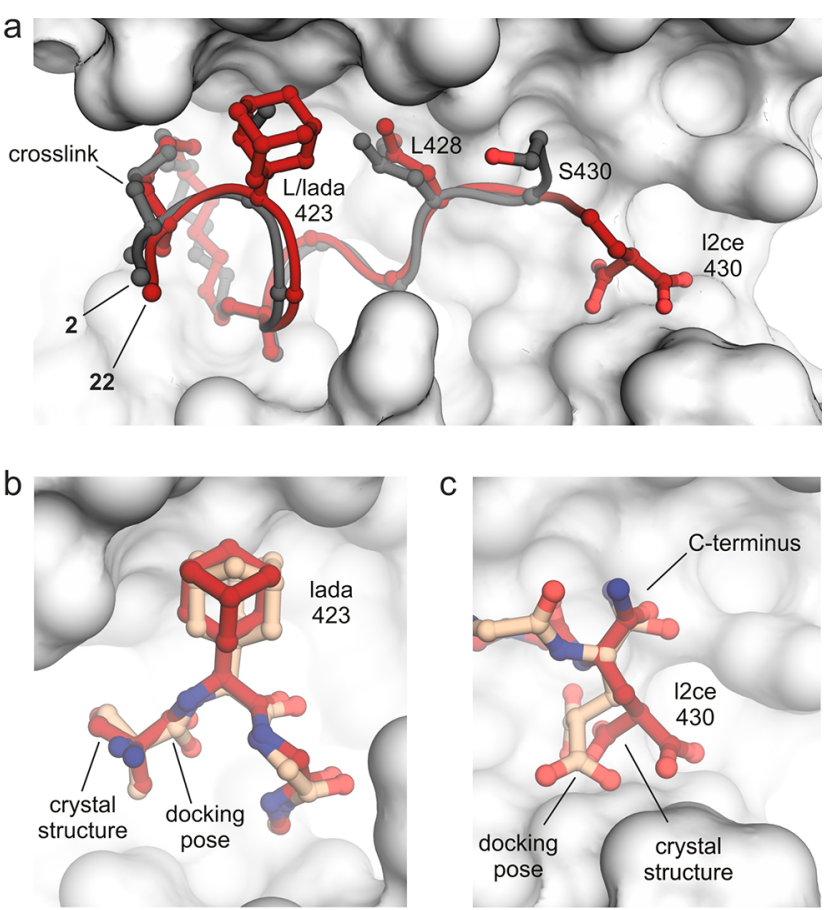

Figure 3. (a) Overlay of crystal structures of 2 (gray, PDB ID 4n84) and 22 (red, PDB ID 5jm4) when bound to $14-3-3 \zeta$ (light gray surface representation). Peptide backbones are shown as ribbons. Varied side chains (423 and 430), hotspot residue L428, and cross-link are shown explicitly. (b,c) Superimposition of $\mathbf{2 2}$ crystal structure (red, PDB ID 5jm4) with predicted structure (orange, pose with highest score) of lada- and 12ce-modified peptide, respectively. Amino acid of interest and backbone of neighboring amino acids are shown explicitly.

lower affinity, 2 (dark gray, $\mathrm{IC}_{50}=1.2 \mu \mathrm{M}$ ) and 1 (light gray, $\left.\mathrm{IC}_{50}=3.3 \mu \mathrm{M}\right)$ exhibit reduced competition.

Finally, it was tested if improved target affinity also results in enhanced activity in cell-based assays. Since fluorescence microscopy indicates very low cellular uptake of these peptides (Figure S13), we aimed at the inhibition of an extracellular 14-

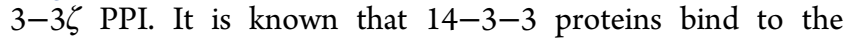
extracellular domain of transmembrane receptor aminopeptidase $\mathrm{N}$ (APN). ${ }^{42,43}$ This interaction presumably occurs between phosphorylated epitopes on APN and the amphipathic groove of $14-3-3$ proteins. ${ }^{33,44}$ It is known that APN-14-33 complex formation induces an intracellular signaling cascade, triggering the expression of a subset of matrix metalloproteinases (MMPs), ${ }^{42,43}$ and that the inhibition of extracellular 14-3-3 can reduce MMP transcription levels. ${ }^{33}$ MMPs are important factors in the modulation of the extracellular matrix, and their upregulation is associated with pathological processes such as rheumatoid arthritis or cancer metastasis. ${ }^{45-47}$ For that reason, MMP inhibition is considered an attractive therapeutic approach. To investigate the potency of 22 in MMP inhibition, we used U87 glioblastoma cells showing robust upregulation of MMP1 mRNA levels $\left(R_{\mathrm{q}}=\right.$ 11.7, Figure 4c) upon treatment with $14-3-3 \zeta(c=200 \mathrm{nM})$. After incubation with a nonlabeled version of $22(c=20 \mu \mathrm{M})$, 14-3-3ל-dependent increase of MMP1 mRNA was drastically reduced (8.6-fold reduction, relative to untreated cells) restoring the levels of nonstimulated cells. Concentrationdependent treatments provide an $\mathrm{IC}_{50}$ value of $8.6 \mu \mathrm{M}$ for 22 (Figure S14), which exceeds the potency of any synthetic competitive inhibitor reported so far. ${ }^{24,28-34}$ Compared to 22

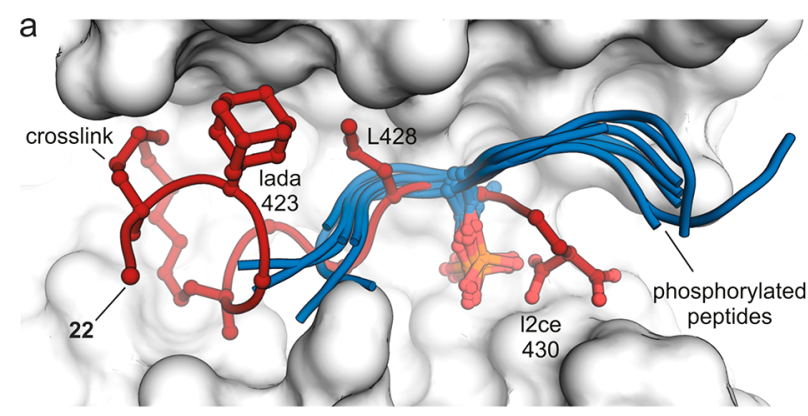

b
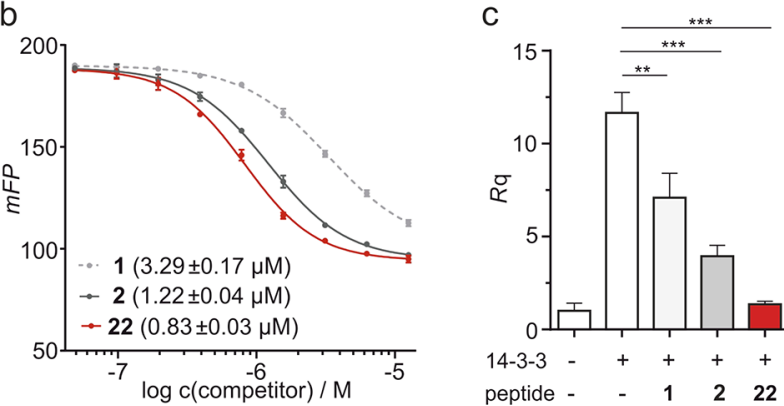

Figure 4. (a) Superimposition of $\mathbf{2 2}$ (red, PDB ID 5jm4) and selected phosphorylated peptides (blue, PDB IDs iqja, 1ywt, 2bn5, 2btp, 2c74, 2npm, 2v7d, 3e6y, and 3nkx) bound to 14-3-3. Peptide backbones are shown as ribbons and important side chains explicitly. (b) FP competition using labeled Raf-peptide as tracer $(10 \mathrm{nM}$ with $2 \mu \mathrm{M}$ 14-3-3) and nonlabeled versions of $\mathbf{1}, \mathbf{2}$, and $\mathbf{2 2}$ (including their $\mathrm{IC}_{50}$ values). (c) Inhibition of $M M P 1$ transcription in a cell-based assay after pathway activation with $14-3-3 \zeta(c=200 \mathrm{nM})$. Cells were treated for $24 \mathrm{~h}$ in the absence and presence of 1,2 , or $22(20 \mu \mathrm{M})$. Expression levels of mRNA were measured by quantitative real time PCR (for details, see Supporting Information).

(8.6-fold reduction), the nonlabeled versions of $\mathbf{1}$ and $\mathbf{2}$ show significantly reduced inhibition of MMP1 transcription (1.6and 3.0-fold reduction, respectively).

\section{DISCUSSION AND CONCLUSIONS}

In conclusion, we report a fast molecular docking approach that allows the affinity maturation of medium-sized modified peptides considering natural and non-natural amino acid variations. The combination of virtual library screening and peptide-adapted molecular docking resulted in a short hit list enriched with 14-3-3 $\zeta$ binders allowing to lower experimental validation efforts dramatically. We utilized a fast molecular docking approach by focusing only on generated binding poses that locate the three hot spot residues at their original positions. As a result, the bound conformation of the core structure is preserved while keeping the termini of the peptide flexible. For the first time, virtual screening of a large macrocyclic peptide library was successfully applied while omitting the use of timeconsuming computational approaches. Notably, the 12 single residue variations (selected from a database of 1446 peptides) contain five hits with submicromolar affinities, which can be useful in the future to improve, e.g., physicochemical properties. The combination of the two highest affinity variations, a hydrophobic and a hydrophilic non-natural amino acid, allowed the design of a peptide with ca. 3-fold increased affinity for 14-

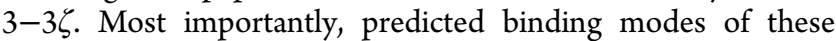
novel side chains were verified by X-ray crystallography underlining the validity of the docking results. The finally evolved macrocyclic PPI inhibitor shows increased potency in 
PPI inhibition and in a cell-based assay. Our computational workflow allows the use of very large databases of non-natural amino acids, e.g., created by in silico methods. Taking into account the broad chemical space accessible with such libraries, it is an appealing strategy for the development of novel peptidebased inhibitors.

\section{EXPERIMENTAL SECTION}

General. For detailed information about experimental procedures, see the Supporting Information. Peptide synthesis was performed on solid support following standard Fmoc-based protocols with macrocyclization and double-bond reduction following previously published procedures. ${ }^{41}$ Peptide purity was determined by RP-HPLC via peak integration at $\lambda=210 \mathrm{~nm}$. All peptides exhibit a purity $\geq 95 \%$. Expression and purification of $14-3-3 \zeta$ (aa 1-230) was performed according to established protocols. ${ }^{24}$

Structure and Library Preparation for Docking. Coordinates from protein-ligand complex were retrieved from PDB entry $4 \mathrm{n} 84$. Water molecules and ions were removed. AutoDock-Tools (ADT) 1.5.6 was used to add polar hydrogens and charges. ${ }^{48}$ For peptides, rotatable bonds were assigned (all substituents including the two peptide sequences were kept flexible except for amide bonds). Twodimensional structures of the 18 natural (Gly and Pro are excluded) and 223 nonproteinogenic amino acids were manually created using ChemDraw 14.0 and subsequently converted to $3 \mathrm{D}$ structures in protonation states under neutral condition using Maestro 9.3.5. ${ }^{49}$ The peptide library was created using in-house Python scripts by replacing single amino acids of $\mathbf{2}$ with each amino acid in the amino acid library.

Docking Engine, Scoring Function, and Docking Experiments. AutoDock Vina 1.1.2 was used as a docking engine. ${ }^{35}$ The center of the grid box was set to $10 / 13 / 10$, and the box size was set to $30 \AA$ in each dimension. Docking parameters were chosen as follows: exhaustiveness $=12$, weight_gauss $1=0.7$, weight_repulsion $=0.5$, weight_hydrophobic $=-0.15$, weight_hydrogen $=-0.6$. (other parameters default). During pose filtering, all poses were excluded in which the functional groups of residues L426, D427, and L428 exhibit an rmsd $>2 \AA$ when compared to analog residues in 2 bound to 143-3 (PDB ID 4n84). For rescoring, the remaining poses were scored with ChemScore ${ }^{39}$ and the Astex statistical potential (ASP), ${ }^{38}$ respectively, using the simplex minimization option as implemented in Gold 5.2.2.4. ${ }^{40}$ For each peptide, only the highest scoring pose was considered for the final ranking. The top five ranking peptides per scoring function and position were visually inspected (in total 60 complexes) to select one peptide per scoring function and position for experimental validation (in total 12 peptides). For selected peptides and their predicted binding modes, see Supplementary Figure S4.

Fluorescence Polarization Assays. A $0.1 \mathrm{mM}$ solution of the corresponding FITC-labeled peptide in DMSO was diluted with FP buffer (10 mM HEPES, $150 \mathrm{mM} \mathrm{NaCl}, 0.1 \%$ Tween-20, $\mathrm{pH} 7.4$ ) to 40 nM. $14-3-3 \zeta$ (a 1-230) was diluted with FP buffer in a 2.5 -fold dilution series $(80 \mu \mathrm{M}-0.5 \mathrm{nM})$ in a 384-well plate. To $15 \mu \mathrm{L}$ of the protein solution, $5 \mu \mathrm{L}$ of the $40 \mathrm{nM}$ peptide stock was added (final peptide concentration, $10 \mathrm{nM}$; final protein concentrations, $60 \mu \mathrm{M}-$ $0.4 \mathrm{nM})$. After $1 \mathrm{~h}$, fluorescence polarization was measured $(\lambda(\mathrm{ex})=$ $485 \mathrm{~nm} ; \lambda(\mathrm{em})=525 \mathrm{~nm})$. The dissociation constant $\left(K_{\mathrm{d}}\right)$ was determined from the binding curve with GraphPad from Prism. For competition experiments, $\mathrm{N}$-terminally acetylated peptides were diluted $1: 1$ in a 384 -well plate $(10 \mu \mathrm{L}, 100 \mu \mathrm{M}-1 \mathrm{nM}) .10 \mu \mathrm{L}$ of a mixture $(1: 1)$ of $14-3-3 \zeta$ (aa 1-230) and TAMRA-labeled cRaf peptide was added (final concentrations: acetylated peptides $=50$ $\mu \mathrm{M}-0.5 \mathrm{nM} ; 14-3-3 \zeta($ aa $1-230)=800 \mathrm{nM}$; TAMRA-labeled cRaf peptide $=100 \mathrm{nM})$. After $1 \mathrm{~h}$, fluorescence polarization was measured $(\lambda(\mathrm{ex})=530 \mathrm{~nm} ; \lambda(\mathrm{em})=585 \mathrm{~nm})$. The half maximal inhibitory concentration $\left(\mathrm{IC}_{50}\right)$ was determined from the binding curve with GraphPad from Prism.

X-ray Crystallography and Structure Determination. 14-3$3 \zeta$ (aa 1-230) was prepared in $50 \mathrm{mM}$ HEPES ( $\mathrm{pH} 7.5$ ), $100 \mathrm{mM}$ $\mathrm{NaCl}$, and $2 \mathrm{mM} \mathrm{MgCl}$. For complexation, 22 was dissolved in DMSO $(11 \mathrm{mM})$ and mixed with the protein in a molar ratio of $1: 2$ (protein/peptide). The complex was incubated overnight at $4{ }^{\circ} \mathrm{C}$ (final protein concentration: $22 \mathrm{mg} / \mathrm{mL}$ ) and set up for crystallization using NeXtal Screens (Qiagen). Crystals grew within 4 weeks in the following condition: $1.36 \mathrm{M}$ sodium citrate and $15 \%(\mathrm{v} / \mathrm{v})$ glycerol and showed a diffraction to $2.34 \AA$. After molecular replacement, the space group was determined to be $P 2_{1} 2_{1} 2_{1}$. Data was collected using PXII beamline for protein crystallography at the Paul Scherrer Institute Swiss Light Source (SLS). Crystallographic analysis was performed using the XDS software package. Molecular replacement was carried out with the CCP4 package, and model building was performed with COOT (Supplementary Table 3). Crystal structure was deposited in the Protein Data Bank (PDB: 5jm4).

Cell Permeability Assay. HeLa cells were grown as a monolayer in $10 \mathrm{~cm}$ tissue culture dishes and cultured in DMEM supplemented with $10 \%$ fetal calf serum, and nonessential amino acids (at $37{ }^{\circ} \mathrm{C}$ in an atmosphere of $5 \% \mathrm{CO}_{2}$ ). For experiments, cells were removed from flasks by treatment with trypsin-EDTA, and 5000 cells were plated in each well of a 96-well microplate and cultured for $24 \mathrm{~h}$. Then, peptides were added at a final concentration of $20 \mu \mathrm{M}$ with $1 \%$ DMSO to the medium and incubated for $4 \mathrm{~h}$. Cells were washed three times with PBS, fixed with $4 \%$ paraformaldehyde, and washed another three times with PBS. For nuclear staining, a $3 \mu \mathrm{M}$ 4',6-diamidino-2-phenylindole (DAPI) solution in PBS was prepared and left on the cells for at least 5 min. After additional washing steps, the cells were left in PBS, and the distribution of FITC-labeled peptides was analyzed via fluorescence microscopy using a $20 \times$ air objective (Axiovert $40 \mathrm{CFL}$, Zeiss).

Quantitative Real Time PCR Analysis. U87 glioblastoma cells were cultivated in DMEM $(+10 \% \mathrm{FCS})$ at $37{ }^{\circ} \mathrm{C}$ at $5 \% \mathrm{CO}_{2}$. Cells were plated for $24 \mathrm{~h}$, and medium was changed (DMEM $+1 \%$ FCS). After another $24 \mathrm{~h}$, cells were treated with $200 \mathrm{nM} \mathrm{14-3-3 \zeta ,} \mathrm{the}$ corresponding peptides in DMEM $+1 \%$ FCS and $0.5 \%$ DMSO. Untreated and $14-3-3 \zeta$-treated controls were cultivated under the same conditions with $0.5 \%$ DMSO. After $24 \mathrm{~h}$ of incubation, total RNA was isolated (Quick-RNA MicroPrep Kit, Zymo Research) and reverse transcribed into cDNA (Quanti Tect Reverse Transcription Kit, Qiagen). Next, cDNA was used for quantitative real time PCR (SensiMix SYBR Low-ROX Kit, Bioline) in the Applied Biosystems 7500 Fast Real Time PCR machine (Thermo Fisher Scientific). For relative quantitation, $2^{-\Delta \Delta \mathrm{CT}}$ method was used with the reference gene GAPDH.

\section{ASSOCIATED CONTENT}

\section{Supporting Information}

The Supporting Information is available free of charge on the ACS Publications website at DOI: 10.1021/acs.jmedchem.7b01221.

Computational setup, peptide synthesis and characterization, protein expression and purification, fluorescence polarization assays, X-ray crystallography and structure determination, cell permeability assay, quantitative real time PCR analysis (PDF)

Highest scored binding mode of 10-21 (ZIP)

Molecular formula strings of peptides (CSV)

\section{Accession Codes}

Crystal structure of 22 in complex with $14-3-3$ has been released as PDB ID 5jm4.

\section{AUTHOR INFORMATION}

\section{Corresponding Authors}

*E-mail: oliver.koch@tu-dortmund.de.

*E-mail: s.hennig@vu.nl.

*E-mail: t.n.grossmann@vu.nl.

ORCID

Christian Ottmann: 0000-0001-7315-0315

Oliver Koch: 0000-0001-9228-217X 
Sven Hennig: 0000-0002-8297-6845

Tom N. Grossmann: 0000-0003-0179-4116

\section{Present Address}

${ }^{\S}$ Department of Cell and Molecular Biology, Uppsala University, BMC Box 596, 75124 Uppsala, Sweden.

\section{Author Contributions}

${ }^{\#}$ These authors contributed equally to this work.

\section{Notes}

The authors declare no competing financial interest.

\section{ACKNOWLEDGMENTS}

We are grateful for support from AstraZeneca, Bayer CropScience, Bayer HealthCare, Boehringer Ingelheim, Merck KGaA, and the Max-Planck-Society. O.K. is funded by the German Federal Ministry for Education and Research (Medizinische Chemie in Dortmund, Grant No. BMBF 1316053). T.N.G. thanks the Deutsche Forschungsgemeinschaft (DFG; Emmy Noether program GR3592/2-1) and the European Reasearch Council (ERC; ERC starting grant, no. 678623). This work was supported by the Collaborative Research Centre 1093, funded by the Deutsche Forschungsgemeinschaft (DFG). We appreciate IT support by C. Schwittek (MPI Dortmund).

\section{ABBREVIATIONS USED}

ACN, acetonitrile; ADT, AutoDock-Tools; APN, aminopeptidase N, CD13; ASP, Astex Statistical Potential; cRAF, $\mathrm{RAF}$ proto-oncogene serine/threonine-protein kinase; DAP, 4',6-diamidino-2-phenylindole; DIPEA, N,N-diisopropylethylamine; DMEM, Dulbecco's modified Eagle's medium; EDT, 1,2-ethanedithiol; FCS, fetal calf serum; FITC, fluorescein isothiocyanate; FP, fluorescence polarization; GAPDH, glyceraldehyde-3-phosphate dehydrogenase; HEPES, 4-(2-hydroxyethyl)-1-piperazineethanesulfonic acid; IPTG, isopropyl- $\beta$-D-1thiogalactopyranoside; $K_{\mathrm{d}}$ dissociation constant (M); MMP, matrix metalloproteinase; NTA, nickelnitrilotriacetic acid; $\mathrm{PEG}_{2}$, 8-amino-3,6-dioxaoctanoyl; PPI, protein-protein interaction; PyBop, (benzotriazol-1-yloxy) tripyrrolidinophosphonium hexafluorophosphate; SASA, solvent accessible surface area; SEC, size exclusion chromatography; SLS, swiss light source; SPPS, solid phase peptide synthesis; TAMRA, 5-carboxytetramethylrhodamine; TCEP, tris(2-carboxyethyl)phosphine; TEV, tobacco etch virus

\section{REFERENCES}

(1) Villar, E. A.; Beglov, D.; Chennamadhavuni, S.; Porco, J. A., Jr.; Kozakov, D.; Vajda, S.; Whitty, A. How proteins bind macrocycles. Nat. Chem. Biol. 2014, 10 (9), 723-731.

(2) Pelay-Gimeno, M.; Glas, A.; Koch, O.; Grossmann, T. N. Structure-based design of inhibitors of protein-protein interactions: mimicking peptide binding epitopes. Angew. Chem., Int. Ed. 2015, 54 (31), 8896-8927.

(3) Sperandio, O.; Reynes, C. H.; Camproux, A.-C.; Villoutreix, B. O. Rationalizing the chemical space of protein-protein interaction inhibitors. Drug Discovery Today 2010, 15 (5-6), 220-229.

(4) Nevola, L.; Giralt, E. Modulating protein-protein interactions: the potential of peptides. Chem. Commun. 2015, 51 (16), 3302-3315.

(5) Milroy, L. G.; Grossmann, T. N.; Hennig, S.; Brunsveld, L.; Ottmann, C. Modulators of protein-protein interactions. Chem. Rev. 2014, 114 (9), 4695-4748.

(6) Passioura, T.; Katoh, T.; Goto, Y.; Suga, H. Selection-based discovery of druglike macrocyclic peptides. Annu. Rev. Biochem. 2014, $83,727-752$.
(7) Heinis, C.; Winter, G. Encoded libraries of chemically modified peptides. Curr. Opin. Chem. Biol. 2015, 26, 89-98.

(8) Rezaei Araghi, R.; Ryan, J. A.; Letai, A.; Keating, A. E. Rapid Optimization of Mcl-1 inhibitors using stapled peptide libraries including non-natural side chains. ACS Chem. Biol. 2016, 11 (5), $1238-1244$.

(9) Falchi, F.; Caporuscio, F.; Recanatini, M. Structure-based design of small-molecule protein-protein interaction modulators: the story so far. Future Med. Chem. 2014, 6 (3), 343-357.

(10) Scott, D. E.; Bayly, A. R.; Abell, C.; Skidmore, J. Small molecules, big targets: drug discovery faces the protein-protein interaction challenge. Nat. Rev. Drug Discovery 2016, 15 (8), 533-550.

(11) Kruger, D. M.; Jessen, G.; Gohlke, H. How good are state-ofthe-art docking tools in predicting ligand binding modes in proteinprotein interfaces? J. Chem. Inf. Model. 2012, 52 (11), 2807-2811.

(12) Hauser, A. S.; Windshugel, B. LEADS-PEP: A benchmark data set for assessment of peptide docking performance. J. Chem. Inf. Model. 2016, 56 (1), 188-200.

(13) Rentzsch, R.; Renard, B. Y. Docking small peptides remains a great challenge: an assessment using AutoDock Vina. Briefings Bioinf. 2015, 16 (6), 1045-1056.

(14) Alogheli, H.; Olanders, G.; Schaal, W.; Brandt, P.; Karlen, A. Docking of macrocycles: comparing rigid and flexible docking in glide. J. Chem. Inf. Model. 2017, 57 (2), 190-202.

(15) Anighoro, A.; de la Vega de Leon, A.; Bajorath, J. Predicting bioactive conformations and binding modes of macrocycles. $J$. Comput.-Aided Mol. Des. 2016, 30 (10), 841-849.

(16) Hochscherf, J.; Lindenblatt, D.; Steinkruger, M.; Yoo, E.; Ulucan, O.; Herzig, S.; Issinger, O. G.; Helms, V.; Gotz, C.; Neundorf, I.; Niefind, K.; Pietsch, M. Development of a high-throughput screening-compatible assay to identify inhibitors of the CK2 alpha/ CK2 beta interaction. Anal. Biochem. 2015, 468, 4-14.

(17) Antes, I. DynaDock: A new molecular dynamics-based algorithm for protein-peptide docking including receptor flexibility. Proteins: Struct., Funct., Genet. 2010, 78 (5), 1084-1104.

(18) Dagliyan, O.; Proctor, E. A.; D'Auria, K. M.; Ding, F.; Dokholyan, N. V. Structural and dynamic determinants of proteinpeptide recognition. Structure 2011, 19 (12), 1837-1845.

(19) Ciemny, M. P.; Debinski, A.; Paczkowska, M.; Kolinski, A.; Kurcinski, M.; Kmiecik, S. Protein-peptide molecular docking with large-scale conformational changes: the p53-MDM2 interaction. Sci. Rep. 2016, 6, 37532.

(20) Audie, J.; Swanson, J. Recent work in the development and application of protein-peptide docking. Future Med. Chem. 2012, 4 (12), 1619-1644.

(21) Allen, S. E.; Dokholyan, N. V.; Bowers, A. A. Dynamic docking of conformationally constrained macrocycles: methods and applications. ACS Chem. Biol. 2016, 11 (1), 10-24.

(22) Lee, H.; Heo, L.; Lee, M. S.; Seok, C. GalaxyPepDock: a protein-peptide docking tool based on interaction similarity and energy optimization. Nucleic Acids Res. 2015, 43 (W1), W431-W435.

(23) Sedan, Y.; Marcu, O.; Lyskov, S.; Schueler-Furman, O. Peptiderive server: derive peptide inhibitors from protein-protein interactions. Nucleic Acids Res. 2016, 44 (W1), W536-W541.

(24) Glas, A.; Bier, D.; Hahne, G.; Rademacher, C.; Ottmann, C.; Grossmann, T. N. Constrained peptides with target-adapted crosslinks as inhibitors of a pathogenic protein-protein interaction. Angew. Chem., Int. Ed. 2014, 53 (9), 2489-2493.

(25) Glas, A.; Wamhoff, E. C.; Krüger, D. M.; Rademacher, C.; Grossmann, T. N. Increased conformational flexibility of a macrocycle-receptor complex contributes to reduced dissociation rates. Chem. - Eur. J. 2017, DOI: 10.1002/chem.201702776.

(26) Schafmeister, C. E.; Po, J.; Verdine, G. L. An all-hydrocarbon cross-linking system for enhancing the helicity and metabolic stability of peptides. J. Am. Chem. Soc. 2000, 122 (24), 5891-5892.

(27) Cromm, P. M.; Spiegel, J.; Grossmann, T. N. Hydrocarbon stapled peptides as modulators of biological function. ACS Chem. Biol. 2015, 10 (6), 1362-1375. 
(28) Cromm, P. M.; Wallraven, K.; Glas, A.; Bier, D.; Fürstner, A.; Ottmann, C.; Grossmann, T. N. Constraining an irregular peptide secondary structure through ring-closing alkyne metathesis. ChemBioChem 2016, 17 (20), 1915-1919.

(29) Wang, B. C.; Yang, H. Z.; Liu, Y. C.; Jelinek, T.; Zhang, L. X.; Ruoslahti, E.; Fu, H. Isolation of high-affinity peptide antagonists of 14-3-3 proteins by phage display. Biochemistry 1999, 38 (38), 1249912504.

(30) Wu, H.; Ge, J. Y.; Yao, S. Q. Microarray-assisted highthroughput identification of a cell-permeable small-molecule binder of 14-3-3 proteins. Angew. Chem., Int. Ed. 2010, 49 (37), 6528-6532.

(31) Arrendale, A.; Kim, K.; Choi, J. Y.; Li, W.; Geahlen, R. L.; Borch, R. F. Synthesis of a phosphoserine mimetic prodrug with potent 14-33 protein inhibitory activity. Chem. Biol. 2012, 19 (6), 764-771.

(32) Bier, D.; Rose, R.; Bravo-Rodriguez, K.; Bartel, M.; RamirezAnguita, J. M.; Dutt, S.; Wilch, C.; Klarner, F. G.; Sanchez-Garcia, E.; Schrader, T.; Ottmann, C. Molecular tweezers modulate 14-3-3 protein-protein interactions. Nat. Chem. 2013, 5 (3), 234-239.

(33) Thiel, P.; Roglin, L.; Meissner, N.; Hennig, S.; Kohlbacher, O.; Ottmann, C. Virtual screening and experimental validation reveal novel small-molecule inhibitors of $14-3-3$ protein-protein interactions. Chem. Commun. 2013, 49 (76), 8468-8470.

(34) Milroy, L. G.; Bartel, M.; Henen, M. A.; Leysen, S.; Adriaans, J. M. C.; Brunsveld, L.; Landrieu, I.; Ottmann, C. Stabilizer-guided inhibition of protein-protein interactions. Angew. Chem., Int. Ed. 2015, 54 (52), 15720-15724.

(35) Trott, O.; Olson, A. J. Software news and update AutoDock Vina: improving the speed and accuracy of docking with a new scoring function, efficient optimization, and multithreading. J. Comput. Chem. 2010, 31 (2), 455-461.

(36) Koch, O.; Jager, T.; Heller, K.; Khandavalli, P. C.; Pretzel, J.; Becker, K.; Flohe, L.; Selzer, P. M. Identification of M-tuberculosis thioredoxin reductase inhibitors based on high-throughput docking using constraints. J. Med. Chem. 2013, 56 (12), 4849-4859.

(37) Kruger, D. M.; Evers, A. Comparison of structure- and ligandbased virtual screening protocols considering hit list complementarity and enrichment factors. ChemMedChem 2010, 5 (1), 148-158.

(38) Mooij, W. T. M.; Verdonk, M. L. General and targeted statistical potentials for protein-ligand interactions. Proteins: Struct., Funct., Genet. 2005, 61 (2), 272-287.

(39) Eldridge, M. D.; Murray, C. W.; Auton, T. R.; Paolini, G. V.; Mee, R. P. Empirical scoring functions 0.1. The development of a fast empirical scoring function to estimate the binding affinity of ligands in receptor complexes. J. Comput.-Aided Mol. Des. 1997, 11 (5), 425-445.

(40) Jones, G.; Willett, P.; Glen, R. C.; Leach, A. R.; Taylor, R. Development and validation of a genetic algorithm for flexible docking. J. Mol. Biol. 1997, 267 (3), 727-748.

(41) Kim, Y. W.; Grossmann, T. N.; Verdine, G. L. Synthesis of allhydrocarbon stapled alpha-helical peptides via ring-closing olefin metathesis. Nat. Protoc. 2011, 6, 761-771.

(42) Ghaffari, A.; Li, Y. Y.; Kilani, R. T.; Ghahary, A. 14-3-3 sigma associates with cell surface aminopeptidase $\mathrm{N}$ in the regulation of matrix metalloproteinase-1. J. Cell Sci. 2010, 123 (17), 2996-3005.

(43) Nefla, M.; Sudre, L.; Denat, G.; Priam, S.; Andre-Leroux, G.; Berenbaum, F.; Jacques, C. The pro-inflammatory cytokine 14-3-3 epsilon is a ligand of CD13 in cartilage. J. Cell Sci. 2015, 128 (17), $3250-3262$.

(44) Ghaffari, A.; Li, Y. Y.; Kilani, R. T.; Ghahary, A. 14-3-3 sigma associates with cell surface aminopeptidase $\mathrm{N}$ in the regulation of matrix metalloproteinase-1. J. Cell Sci. 2010, 123 (17), 2996-3005.

(45) Jiang, W. G.; Sanders, A. J.; Katoh, M.; Ungefroren, H.; Gieseler, F.; Prince, M.; Thompson, S. K.; Zollo, M.; Spano, D.; Dhawan, P.; Sliva, D.; Subbarayan, P. R.; Sarkar, M.; Honoki, K.; Fujii, H.; Georgakilas, A. G.; Amedei, A.; Niccolai, E.; Amin, A.; Ashraf, S. S.; Ye, L.; Helferich, W. G.; Yang, X.; Boosani, C. S.; Guha, G.; Ciriolo, M. R.; Aquilano, K.; Chen, S.; Azmi, A. S.; Keith, W. N.; Bilsland, A.; Bhakta, D.; Halicka, D.; Nowsheen, S.; Pantano, F.; Santini, D. Tissue invasion and metastasis: Molecular, biological and clinical perspectives. Semin. Cancer Biol. 2015, 35, S244-S275.
(46) Nagase, H.; Visse, R; Murphy, G. Structure and function of matrix metalloproteinases and TIMPs. Cardiovasc. Res. 2006, 69 (3), $562-573$.

(47) Konttinen, Y. T.; Ainola, M.; Valleala, H.; Ma, J.; Ida, H.; Mandelin, J.; Kinne, R. W.; Santavirta, S.; Sorsa, T.; Lopez-Otin, C.; Takagi, M. Analysis of 16 different matrix metalloproteinases (MMP-1 to MMP-20) in the synovial membrane: different profiles in trauma and rheumatoid arthritis. Ann. Rheum. Dis. 1999, 58 (11), 691-697.

(48) Morris, G. M.; Huey, R.; Lindstrom, W.; Sanner, M. F.; Belew, R. K.; Goodsell, D. S.; Olson, A. J. AutoDock4 and AutoDockTools4: Automated docking with selective receptor flexibility. J. Comput. Chem. 2009, 30 (16), 2785-2791.

(49) Maestro, version 9.7; Schrodinger LLC: New York, 2014. 